\title{
What can be done to improve radiology residency education? Evaluation of the outcomes of a training course
}

\author{
Ahmet ASLAN*, Murat ACAR**, Mine ASLAN***, Murat AŞIK****
}

SUMMARY

We aimed to present the current status in radiology resident education in Association of Public Hospitals of Northern Anatolian Region of Istanbul (IANR-PHA) as expressed through the views of radiology residents using the outcome of a training course and the suggestions made by residents for achieving a better radiology resident education. The study designed a sa cross-sectional study. A training course was given to 34 radiology residents from five different training and research hospitals (institutions) in IANR-PHAfor 31 weeks. At the end of the training course, a questionnaire and an assessment exam were applied to all radiology residents for collecting data. The infrastructure of institutions and the contribution of the training course to residents' radiological knowledge and skills were evaluated using a Likert-type scale. The infrastructure of institutions were below average in IANR-PHA. The infrastructure of the institutes had a moderate and positive effect on the assessment exam ( $r=0.52$ and $p=0.008$ ). According to radiology residents, the infrastructure of institutions in IANR-PHA was below the average for the radiology resident education. A new education model including training in subbranches of radiology in qualified institutions and continuous training courses with workshops, could improve the inadequate infrastructure of the institutions.

Key words: Radiology, education, radiology residency training, qualified educator, accreditation systems
ÖZET

Radyoloji uzmanlık eğitimini geliştirmek için neler yapılabilir? Eğitim kursu değerlendirmesi

İstanbul Anadolu Kuzey Kamu Hastaneler Birliğinde (İAKKHB) bulunan radyoloji asistanlarına yönelik yapılan ĕgitim kursundan sonra güncel radyoloji ihtisas eğitiminin durumunu ortaya koymak ve daha iyi bir radyoloji uzmanlık eğitimi için onların önerilerini sunmayı amaçladık. Çalışma kesitseldir. IAKKHB'de bulunan 5 eğitim ve araştırma hastanesinde çalışan 34 radyoloji uzmanlı öğrencisine 31 hafta süre ile eğitim kursu düzenlendi. Kurs sonunda tüm uzmanlık ögrencilerine anket ve değerlendirme sinavı yapıldı. Eğitim ve araştırma hastanelerindeki altyapı ve eğitim kursunun radyolojik bilgi ve becerilerine katkıları Likert tipi skala ile de ğerlendirildi. İAKKHB'deki radyoloji eğitimi altyapısı ortalamanın altındadır. Hastanelerin yetersiz altyaplsi de ğerlendirme sınavını orta ve positif yönde etkilemektedir $(r=0.52$ and $p=0.008)$. Radyoloji uzmanlık öğrencilerine göre IAKKHB'deki hastanelerin, radyoloji eğitimi açısından altyapısı ortalamanın altındadır. Öğrencilerin radyoloji alt bölümlerinden

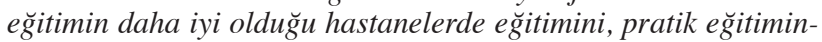
de olduğ u ĕ̆itim kurslarının devamını da içeren yeni bir ĕ̆itim modeli, hastanelerin yetersiz altyap sorununu giderebilir.

Anahtar kelimeler: Radyoloji, ĕgitim, radyoloji uzmanlık ĕgitimi, yetkin eğitici, akreditasyon sistemleri

\section{INTRODUCTION}

Radiology is far more than a single medical image obtained by X-rays and has great importance in medicine with imaging of all disease processes from each medical discipline, including treatments in some cas- es ${ }^{(1)}$. X-rays, ultrasound and radiofrequency waves are used in clinical radiology and the technology and equipment used in radiology are evolving quickly ${ }^{(2)}$. Thus, knowledge about imaging and interpretation of images for the care of patients require a special education.

Geliş tarihi: 26.04.2015

Kabul tarihi: 25.05.2015

*Department of Radiology, Dr. Siyami Ersek Thoracic and Cardiovascular Surgery Training and Research Hospital

**Department of Radiology, Medical School of Medeniyet University

***Department of Radiology, Ümraniye Training and Research Hospital

****Department of Radiology, Göztepe Training and Research Hospital

Yazışma adresi: Dr. Ahmet Aslan, Department of Radiology, Dr. Siyami Ersek Thoracic and Cardiovascular Surgery Training and Research Hospital, Istanbul

e-mail: aslahmet@gmail.com 
Radiology resident education is based on theoretical and practical training, and it is organized and audited in Turkey by the Turkish Ministry of Health ${ }^{(3)}$. Residents in Turkey are trained according to a standing rule for radiology speciality training either at a medical university hospital or at a training and research hospital (institution) with established training curriculums that include training in all imaging modalities and also a rotation in a nuclear medicine clinic. But established training curriculums are not applied (or partially applied) and are not strictly monitored by the Ministry of Health or any accredited institution. Also, these training curriculums are different for each institution due to variability in factors such as infrastructure, equipment, and qualified educators. Inadequate infrastructure of training hospitals for medical imaging equipment and insufficient number of educators limit the education of radiology residents and make radiology education a serious problem for residents. The aim of this study was to present the current status of radiology resident education through the views of radiology residents using the outcome of a training course organized for residents in the Association of Public Hospitals of Northern Anatolian Region of İstanbul (IANR-PHA). Residents' suggestions for achieving better radiology resident education are also presented.

\section{Subjects and Methods}

\section{Population}

This cross-sectional study was approved by the Institutional Ethics Committee. A total of 34 radiology residents from five different training and research hospitals in IANR-PHA were given a training course for 31 weeks between November 2013 and June 2014.

\section{Training course}

The training course was organized by IANR-PHA and Istanbul Medeniyet University to improve and equalize radiology resident education. The training course was based on theoretical education and it was given to radiology residents by 23 educators from 11 different institutions. The residents were divided into two groups as senior or junior residents according to their duration of education as less than or more than two years and they were trained on separate days on the same issues. The daily duration of the training was two hours. The training course was composed of lectures on abdominal radiology, thoracic radiology, musculoskeletal system radiology, pediatric radiology, neuroradiology, breast radiology, obstetric imaging, cardiovascular imaging and physics of imaging modalities. At the end of the training course, a questionnaire and an assessment exam forms were given to all residents.

\section{Questionnaire}

At the end of the training course, residents were asked to complete a 12-item questionnaire concerning their institutions, the difference in their radiological knowledge and skills before and after the training course, and their suggestions for better radiology resident education and for the next training course before the assessment exam.

The questionnaire was designed in two parts. In the first part, residents were requested to evaluate the infrastructure and radiological equipment, the number of qualified educators, the presence of a core curriculum, compliance with clinical rotations assessed by standing rules at their institution. In the second part, the training course was evaluated by asking the residents whether they were pleased to be trained with other residents and the contribution of the training course to their theoretical and practical knowledge in radiology. A Likert-type scale was used to evaluate the infrastructure of their institution and the contribution of the training course to their radiological knowledge and skills. Residents were asked to score their training, and infrastructure of on a scale from 1 to 5 , with 1 as none and 5 as very good. The questions asked about infrastructure of the institution were designed to evaluate the resident's room, meeting room, reporting room, waiting and scanning rooms for magnetic resonance imaging (MRI), computed tomography (CT) and ultrasonography (US), quality of MRI and CT images, adequacy of equipment and number of educators. The contribution of the training course to their radiological knowledge and skills were evaluated by 
asking them to score US and color Doppler US, abdominal radiology, thoracic radiology, musculoskeletal system radiology, neuroradiology, breast radiology, vascular and non-vascular interventional radiology, and plain X-ray image training. Residents were also asked to answer if they were pleased to be trained with other residents, and if there was any contribution of the training course to their radiology education. as yes or no. The questions of whether this training course should be repeated the next year and whether adding practical training in the form of workshops into the next year's training course was necessary were asked and the answers were classified as no, does not make a difference, and should be carried out.

Suggestions and concerns of residents for radiology resident education were noted and classified.

\section{Assessment exam}

An assessment exam was performed in a test form that included 32 questions received from 23 educators to evaluate the contribution of the training course to the radiological knowledge of the residents. The assessment exam scores of residents were evaluated between 0 and 100 points, with 0 point being poorly trained and 100 points as being perfectly trained. No threshold score was set for the success of the training course. The exam scores were grouped according to the institution of the residents.

\section{Collecting data}

The name of the training institution was specified in the questionnaire, but the name, sign or signature of the resident were not. While collecting the data from the questionnaire, the name of the institution of the resident was censored. Answers for the questionnaire were collected by one of the authors who was blind to the affiliation of the resident. Then, one of the other authors classified the collected data and the results of the assessment exam according to the institutions.

\section{Statistical analysis}

The Statistical Package for Social Sciences 16.0 (SPSS Inc., Chicago, Illinois, USA) was used for the statistical analysis of the collected data on a personal computer. Categorical variables were presented as numbers or percentages and non-parametric variables as median (range). Scores for evaluating the infrastructure of institutions in the first part were evaluated for a correlation between the scores of the theoretical education, contribution of the training course to their radiological education and the mean score of the assessment exam according to the residents' institutions by Spearman correlation coefficient. Correlation coefficients of 0.2-0.4 were deemed as weak, 0.4-0.7 as moderate and $>0.7$ as strong correlations. Statistical significance was set as $\mathrm{p}<0.05$.

\section{RESULTS}

Thirty-four radiology residents training at five different institutions were included in the training course. The response rate to the questionnaire and the participation rate for the assessment exam were presented in Table 1.

Table 1. Participation of radiology residents to the questionnaire and the assessment exam according to their institutes as senior or junior.

\begin{tabular}{lccccc}
\hline & \multicolumn{2}{c}{ Questionniare } & & \multicolumn{2}{c}{ Assessment Exam } \\
\cline { 2 - 3 } \cline { 5 - 6 } Institutes & Senior RR & Junior RR & & Senior RR & Senior RR \\
\hline Institute 1 & $4(100 \%)$ & $4(100 \%)$ & & $4(100 \%)$ & $4(100 \%)$ \\
Institute 2 & $3(60 \%)$ & $\mathrm{NP}$ & & $1(20 \%)$ & $\mathrm{NP}$ \\
Institute 3 & $2(100 \%)$ & $5(100 \%)$ & & $2(100 \%)$ & $5(100 \%)$ \\
Institute 4 & $5(83.3 \%)$ & $2(66.6 \%)$ & & $3(50 \%)$ & $2(66.6 \%)$ \\
Institute 5 & $1(100 \%)$ & $4(100 \%)$ & & $1(100 \%)$ & $3(75 \%)$ \\
Total & $15(83.3 \%)$ & $15(93.75 \%)$ & & $11(61.1 \%)$ & $14(87.5 \%)$ \\
\hline
\end{tabular}

Abbreviations: $R R$; radiology resident, NP; no participation.

The number of educators varied among institutions as follows: $\mathrm{n}=7,2,5,2$, and 2 in institutions $1,2,3,4$, and 5, respectively. Median scores of the infrastructure and the contribution of the training course to residents' education and the mean scores of the assessment exam according to institutions are given in Table 2. Spearman correlation analysis between the infrastructure of the institutions, scores of the assessment exam and contribution of the training course to radiological knowledge are given in Table 3. The contribution of the training course to the radiological knowledge of residents according to the subbranches of radiology is given in Table 4 . 
Table 2. Scores of institutes regarding infrastructure and mean scores of the contribution of the training course to resident education and the assessment exam.

\begin{tabular}{|c|c|c|c|c|c|}
\hline Scores & Institute 1 & Institute 2 & Institute 3 & Institute 4 & Institute 5 \\
\hline Infrastructure* & $3(1-5)$ & $3(1-4)$ & $2(1-4)$ & $2(2-4)$ & $1(1-4)$ \\
\hline Contribution of $\mathrm{TC}^{*}$ & $4(1-5)$ & $3(2-4)$ & $3(1-5)$ & $3(1-4)$ & $2(1-4)$ \\
\hline Assessment exam** & $76.75 \pm 8.79$ & 75.00 & $66.85 \pm 5.36$ & $56.40 \pm 14.20$ & $50.90 \pm 8.93$ \\
\hline
\end{tabular}

*Scores are given as median (range).

**Scores are given as mean $( \pm S D)$.

Abbreviations: TC; training course.

Table 3. Correlations between the infrastructure of the institutes, contribution of the training course and the assessment exam.

\begin{tabular}{llcc}
\hline Correlation & & Contribution of the TC & Assessment ES \\
\hline Infrastructure & $\mathrm{r}^{*}$ & 0.182 & 0.520 \\
of the institute & $\mathrm{p}$ & 0.335 & 0.008 \\
& $\mathrm{n}$ a & 30 & 25 \\
Contribution & $\mathrm{r}^{*}$ & - & 0.465 \\
of the TC & $\mathrm{p}$ & - & 0.019 \\
& na & - & 25 \\
\hline
\end{tabular}

* Spearman Correlation Coefficient, a Number

Abbreviations: TC; training course, ES; exam score.
Residents answered that in institution 1 and 2 the core curriculum was present and educators comply with the necessary clinical rotations assessed in standing rules for radiology medical specialty training. Training together with the other residents in IANR-PHA pleased all residents (100\%). Twenty-eight residents said that the training course made a contribution to their radiology education and the training course should be carried out next year with workshops $(93.3 \%)$.

Table 4. Contribution of training course to radiology education.

\begin{tabular}{|c|c|c|c|c|c|c|}
\hline & Institute 1 & Institute 2 & Institute 3 & Institute 4 & Institute 5 & Total \\
\hline US and color Doppler US RE $\mu$ & $2(1-4)$ & $3(2-4)$ & $1(1-3)$ & $1(1-3)$ & $1(1-3)$ & $1.5(1-4)$ \\
\hline Abdominal $\mathrm{RE} \mu$ & $5 \quad(4-5)$ & $4(3-4)$ & $4(3-5)$ & $4(3-4)$ & $3(2-4)$ & $4 \quad(2-5)$ \\
\hline Thoracic $\mathrm{RE} \mu$ & $4 \quad(3-5)$ & $4(3-4)$ & $3(2-4)$ & $3(3-4)$ & $2(2-4)$ & $4 \quad(2-5)$ \\
\hline Musculoskeletal System RE $\mu$ & $4 \quad(3-5)$ & $4(3-4)$ & $3(3-4)$ & $4(3-4)$ & $3(2-4)$ & $3.5(2-5)$ \\
\hline Neuroradiology Education $\mu$ & $3.5(3-4)$ & $3(3-4)$ & $2(2-4)$ & $3(2-4)$ & $2(2-4)$ & $3(2-4)$ \\
\hline Breast $\mathrm{RE} \mu$ & $4 \quad(3-5)$ & $3(3-4)$ & $4(2-5)$ & $3(2-4)$ & $3(1-4)$ & $3.5(1-5)$ \\
\hline Non-vascular Interventional RE $\mu$ & $1 \quad(1-3)$ & $3(2-3)$ & $1(1-3)$ & $2(1-3)$ & $1(1-1)$ & $1(1-3)$ \\
\hline Vascular Interventional $\mathrm{RE} \mu$ & $1 \quad(1-2)$ & $3(2-4)$ & $2(1-4)$ & $1(1-3)$ & $1(1-1)$ & $1 \quad(1-4)$ \\
\hline Plain Radiographs RE $\mu$ & $3 \quad(2-4)$ & $3(2-3)$ & $3(2-4)$ & $3(3-4)$ & $3(2-3)$ & $3(2-4)$ \\
\hline
\end{tabular}

$\mu$ Scores are given as median (range).

Abbreviations: US; ultrasonography, RE; radiology education.

Eleven radiology residents who responded to the questionnaire did not make any suggestions for radiology education in their institutions or PHA. Suggestions of 21 residents were classified and were mostly about the content of the training course, such as increasing the amount of practical education in terms of workshops, discussion of cases, and presenting the lectures with more radiological images. They suggested that the training curriculum in the PHA should be well organized and strictly audited by an experienced educator in the PHA. They also suggested that educators should seek help to offer better radiology training, such as improving their teaching skills and methods.

\section{DISCUSSION}

The final version of the revised training curriculum for clinical radiology training requirements for residents, educators and institutions in Europe was established and declared in February 2014 by the European Society of Radiology (ESR) ${ }^{(4)}$. But there are challenges in implementing this curriculum in Turkey. Up to now, the applied core curriculum in the radiology specialty training has been different for each training institution and depended on several factors, such as the competency in the infrastructure and equipment and the number of qualified educators. The Turkish Society of Radiology (TSR) established an extended training curriculum in November 2014 and described 
what should be included in radiology resident education in Turkey. But as stated in the preface to the extended training curriculum, they only made suggestions for better radiology resident education with no sanctions and no organized accreditation system. Therefore, in Turkey the follow-up and evaluation systems for the training institutes, extended training curriculum and residents have not been well organized ${ }^{(3)}$. A radiology training course provided for the radiology residents in IANR-PHA, was organized to improve and to standardize the quality of radiology resident education in IANR-PHA. A questionnaire was given to radiology residents after the training course to collect data about the training course and the infrastructure of their institutions. The residents stated that the training course was beneficial for them and should be repeated with workshops in the coming years. They also had complaints about the insufficient infrastructure, the number and training methods of educators, and applied or partially applied training curricula in their institutions.

Radiological equipment in the public hospitals, institutions and medical schools of universities in Turkey are mostly under the control of subcontracting companies due to unsatisfactory investments of the Turkish Ministry of Health and of universities in the hospitals. These companies are interested in the service of medical care, not the training of residents which limits the access of residents to all radiological modalities and patients. Educators, residents and training curriculum were to be evaluated by the educators and residents according to the final standing rule, but the infrastructure of the training institutes are insufficient and accreditation by a private and independent institution is still absent ${ }^{(3)}$. Consequently, training departments are not checked for efficiency of radiological equipment or training materials. Poor, variable, and nonstandardized infrastructure of the institutions does not meet residents' demands in radiology education and does not encourage them to excel. To our knowledge, there has been no study concerning the effect of infrastructure of institutions on resident education in radiology in Turkey. In our study, the infrastructure of the training departments in IANR-PHA was below average which also demonstrated a moderate and a positively significant correlation with assessment exam scores. Our statistical data for evaluating the infrastructure of the institutions were obtained from the responses of the residents, not from an independent organization. This could decrease the reliability of our results. But we thought that the correlation with the assessment exam scores was remarkable. Institution 1, which has the largest number of educators and high scores for the infrastructure of the institution, had the best outcomes while institution 5, which has a small number of educators and lower scores for infrastructure of the institution, had the poorest outcomes when we compared the scores of the assessment exam.

Radiology residents in IANR-PHA complained about the insufficient number of qualified educators. Policies of the Turkish Ministry of Health, laws organizing the work of doctors both in medical schools of universities and in public hospitals, and the restriction and limitation in employment of qualified educators have decreased the number of educators and impeded the transmission of knowledge, skills and experience. Also, according to the final standing rule for medical speciality education in Turkey, institutions are forced to obey the defined training curriculums by the National Board of Expertise in Medicine, but sanctions are not strictly applied ${ }^{(3)}$. This problem displayed itself as an absence or only partial compliance with the core curriculum and clinical rotations, which are serious problems for radiology residents in their education in IANR-PHA. Interestingly, in our study, according to the radiology residents, education in subbranches of radiology in each institution differed and education in one subbranch of radiology was better than the education in other institutions, which can be related to the special interest of the educators or institutions. This discrepancy can be addressed in a new training model in which residents can perform their rotations in subbranches of radiology for defined durations at institutions with a better infrastructure. The training curriculum envisaged by ESR advised a similar model, in which residents could also access into other medical departments by affiliation with a university hospital or a large training hospital ${ }^{(4)}$. Thismodel with training 
courses including workshops may help to eliminate inequalities and can aid in standardization of resident education.

Residents were pleased to be a part of this training course and wish it to be repeated in subsequent years. Suggestions of the residents indicated that educators show insufficient attention and ability in radiology education, which should be their mission. Similar to training courses for residents, educators could be administered a training course for improving their teaching skills ${ }^{(4)}$. Additionally, a feedback mechanism for evaluation of educators by residents, which was also stated in the last standing rule for medical speciality education in Turkey, may be helpful ${ }^{(3)}$. Residents also stated that training curricula should be monitored and audited by one of the experienced educators in IANR-PHA.

Our study has several limitations. Firstly, our methodology was not appropriate for making a general assessment of radiology residency education in Turkey, which has its own parameters. This study primarily focused on evaluation of the outcomes of the training course and additionally demonstration of the problems in radiology residency education in IANRPHA through the residents' views. Further studies on radiology residents and educators from both medical schools of universities and training and research hospitals in different PHA's with appropriate evaluation criteria based on ESR training curriculum for radiology would be helpful to show the effect of infrastructure on radiology resident education and could be useful for planning and organizing extended radiology training curricula. Secondly, a similar questionnaire and assessment exam could be applied before the training course to show the effect of the training course on the radiological knowledge and skills of the residents more objectively. We also did not investigate the background of the residents and their former radiology practice, which could potentially affect the assessment exam. Thirdly, the assessments and suggestions were based on the answers of residents and it should be kept in mind that they were subjective opinions ${ }^{(5)}$. We could also apply a questionnaire for educators to investigate problems and obtain their suggestions on radiology resident education.

\section{CONCLUSION}

Radiology residents in IANR-PHA were pleased with the training course and strongly recommended that it should be repeated next year. Overall, a new education model, which TSR will put in effect, including training in subbranches of radiology in qualified institutions and continuous training courses with workshops, can alleviate the unfavourable effect of the limited number of qualified educators and poor infrastructure of the institutions on the education of radiology residents, and may improve the level of radiology resident education by eliminating inequalities among institutions.

\section{Acknowledgements}

We thank all of the radiology residents, their institutions and the Association of Public Hospitals of Northern Anatolian Region of İstanbul for their kind cooperation and contributions. Also, we also gratefully acknowledge Drs Fatih Tufan, Sinan Tan, and Sinan Şahin for their constructive comments during the writing of this paper.

This study was presented as a poster at the $35^{\text {th }} \mathrm{Na}-$ tional Congress of Radiology, November 11-16, 2014 at Antalya, Turkey

\section{Conflict of interest disclosure}

The authors declare no conflicts of interest.

\section{REFERENCES}

1. Sohoni C. Radiology education needs a revamp. Indian J Radiol Imaging 2011;21:156.

http://dx.doi.org/10.4103/0971-3026.82288

2. Lee JS, Aldrich JE, Eftekhari A, et al. Implementation of a new undergraduate radiology curriculum: experience at the University of British Columbia. Can Assoc Radiol J 2007;58:272-278.

3. Final standing rule for medical specialty education in Turkey. Available at: www.tuk.saglik.gov.tr/tuey-2014.pdf. Accessed April 26, 2014.

4. Final training curriculum for radiology residents envisaged by European Society of Radiology. Available at: http://www.myesr.org/html/img/pool/20_08_2014_ESR_2013_ESR-EuropeanTrainingCurriculum_web.pdf. Accessed August 20, 2014.

5. Sezik S, Aksay E, Temizyürek Z, et al. A national survey of Turkish emergency residents' perspectives regarding rotation effectiveness. Tr J Emerg Med 2012;12:8-14. http://dx.doi.org/10.5505/1304.7361.2012.93270 